\title{
Contribution of Job Nature on Leadership Style among Academia
}

\author{
Milan Shrestha ${ }^{1}$
}

Article History

Received 2019-04-28

Accepted 2019-05-11

Published 2019-06-01

Keywords

Leadership styles

Autocratic

Democratic

Laissez-faire

Job nature

\section{How to cite?}

Shrestha, M. (2019). Contribution of Job

Nature on Leadership Style among

Academia. SEISENSE Journal of

Management, 2(4), 1-13. doi:

$10.33215 /$ sjom.v2i4.156

\author{
Kathmandu University School of Education, Nepal
}

\begin{abstract}
Purpose- Effective leadership practices in schools are only possible while headmaster and teachers adopt suitable leadership styles. The main purpose of this study is to identify the leadership styles as well as determine the association of democratic, autocratic and laissez-faire leadership style with each other among school teachers.
\end{abstract}

Design/Methodology- This study is based on post-positivist research philosophy and cross-sectional survey as the research design which is confirmatory and explanatory in nature. It gathered the data via self-administer questionnaire from 345 school teachers and analyzed through descriptive statistics and parametric test.

Findings- The researcher derived that school teachers adopted a more democratic leadership style and gave least prefer to the laissez-faire leadership style in schools. Meanwhile, the lacking of equal facility and access to power exercise contributes to making significant differences in leadership styles across the job nature of school teachers. Furthermore, this study assess that there is no relationship between autocratic, democratic and laissez-faire leadership styles. These distinct styles of leadership may develop the differences in work performances of school teachers.

Practical Implications- This research provides the framework for another future researcher to investigate the input of job nature on leadership style among school teachers.

\footnotetext{
${ }^{1}$ Corresponding authors email address: milanshrestha313244@gmail.com
} 


\section{Introduction}

Effective leadership and leader are being an integral part of every successful organization to achieve their goals. These successful organizations are led by the effective leaders who can well understand the complexities of rapidly changing pattern of the globe (Nanjundeswaraswamy \& Swamy, 2014) and competitive organization. Thus, leadership is the universal process where leaders influence their followers for achieving a common goal of the organization (Northouse, 2010). So the leaders and followers, both have some certain sorts of qualities. For instance, followers consist good judgment, ethics, honesty, discretion, etc (McCallum, 2013) and leaders incorporate qualities like decisiveness, loyalty, integrity, managerial competencies, charisma, etc (Fries, 2018). These both sorts of qualities are posed by all individuals. As a result, the existence of these leadership qualities contributes to reflect the leadership styles in each individual. In addition, these leadership qualities are not the same in every individual so leadership styles are also different to each individual.

A leadership style is defined as a leader's technique while providing direction, motivating people and implementing plans in the organization to achieve the pre-determined goals. In this context, Lester (1975) asserts "each person's leadership style has an important bearing on how effectively an organization reaches its objectives" (p. 3). Similarly, Nyiha (2015) argued leadership style as the manner and approach of the leaders in which a leader shows direction, execute the plans and encourage the people to achieve organizational goals. More specifically, the manner and approaches of leaders are distinct with each other. This distinctive features and qualities residing in leaders contribute to identifying the different types of leadership style among school teachers. Fundamentally, many authors classify leadership styles in three types; autocratic, democratic and laissez-faire (Drobot \& Rosu, 2012; Fentiman-Hall, 2017; Hafez, 2017; Kumari, 2016) respectively. Almost leader possess these all type of leadership styles. Nonetheless, the degree of these leadership styles is only varying from others. It is analogous to Tannenbaum and Schmidt's Leadership Continuum where they claim that leadership styles lie between the scale of "authoritarian" and 'democratic' poles (Clayton, 2017; Dudovisky, 2013). The execution of these leadership styles determines the entire leadership process (Lester, 1975) in schools and further drives to achieve the organizational goals (Germano, 2010).

The leadership styles are worthwhile for job satisfaction (Mwaisaka, K'Aol, \& Ouma, 2019; Rahmat, Ramly, Mallongi, \& Kalla, 2019) and fruitful organizational performances (Ojokuku, Odetayo, \& Sajuyigbe, 2012). It resonates with Igbaekemen and Odivwri (2015) who believe that these leadership styles being the causative factors for maintaining job satisfaction, organizational citizenship behavior among school teachers, achieving work effectiveness and educational achievement among students. As well as these leadership styles ultimately contribute to the entire institutional development of the school. Kale and Ozdelen (2014) claim that the teacher leadership is associated with improving schools and they further mentions "effective schools are closely linked to effective leadership practices" (p. 228). These effective leadership practices in schools are only possible while headmaster and teachers adopt suitable leadership styles.

So, this study aims to explore the leadership style and examine the relationship between types of leadership styles among school teachers. In addition, this study also assesses the influences of job nature in leadership styles. Similarly, it tries to address queries like: In what extent the leadership styles are adopted in Schools? Does the nature of the job vary the leadership styles of school teacher? What is the relationship between leadership styles among academia? Among these prime queries, the researcher determined, "In what extent, Does the leadership styles are associated with each other among school teachers?" as a study dilemma to deal in this research. 


\section{Literature Review}

\section{Autocratic Leadership Style}

The autocratic leadership style is the phenomena of leadership where the leader has entire control over all decisions making the process (Khan et al., 2015). While the rest of the members has got very few chances to give input in this decision-making the process in the organization. In the words of Adyyemi (2011), it can also be called as the authoritarian leadership style. This type of leadership takes full control of the team as well as the organization and provides low autonomy to the groups. Nyiha (2015) claims "In this case, the teacher has a feeling that he/she is not appreciated thus losing job satisfaction" (p. 16). As a result, this leadership style is effective when the organizational situation is harsh. However, it does not work effectively in all situations mainly in a normal state of affairs.

\section{Democratic Leadership Style}

The democratic leadership style is also known as the participative leadership style (Khan et al., 2015). In this leadership style, all team members actively participate in the decision making process of the organization (Bhatti, Maitlo, Shaikh, Hashmi, \& Shaikh, 2012) and ultimately leader takes decision based on the group participation. Adeyemi (2011) states “The leader's attempts as much as possible to make each individual feel that he is an important member of the organization" (p. 85). This leadership style contributes to enhancing the high degree of morale among employees which always assists to achieve high performance in the organization.

\section{Laissez-fair Leadership Style}

The laissez-fair leadership style hand over the responsibilities of other members and avoid decision making in the organization (Chaudhary \& Javed, 2012). In another term this leadership lets the group members make all decision in the organization, therefore, some authors defined it as "hands-off leadership" (Tarsik, Kassim, \& Nasharudin, 2014, p. 3) and "zero leadership" (Yang, 2015). In this leadership style, leaders do not or provide little information, guidance and direction to the staffs and gives freedom in the organization. This leadership style look like a simple and easy going process between leaders and employees (Tarsik et al., 2014). According to Sandling (2014), laissez-fair leaders engage in formulating the goals and seek work accomplished independently by their members in the organization. This freedom in the job drives motivation (Gaskell, 2016) and creates enthuse among staff in an organization. However, it also creates confusion and uncertainty in employees (Skogstad, Einarsen, Torsheim, Aasland, \& Hetland, 2007) due to lack of proper instruction.

\section{Leadership Style and Job nature}

The leadership style is the organizational behavior associated with the employee's job nature. Furthermore, the job nature of the employees is linked with job security. The job security is the prime concern in the leadership process which inspires and motivates employees to do their job well. In this context, the Ministry of Education, Science, and Technology (MOEST, 2018) confines the teachers' job nature in three categories; approved (Permanent), contract (Rahat) and temporary (Niji-Shrot). This category of teachers reflects the status of permanency and temporarily in relation to their job. For instance, if the employees are in permanent status, they feel highly secure in their job (Balz, 2017) and give a high performance (Lucky, Minai, \& Rahman, 2013 ) in their work. In addition, the permanent job holders are more inspired, motivated and enthusiastic in the job. As a result, high achievement, productivity, and effectiveness occur in an organization. That is why; the job nature plays a crucial role as a catalyst in the leadership process in terms of inspiration, motivation, and followership among school teachers. Thus, the job nature among school teachers contributes to determining the leadership style. For this reason, the researcher hypothesized as: 
$\mathrm{H}_{1}$ : The nature of the job varies the leadership styles of school teachers.

\section{Relationship between Autocratic, Democratic, and Laissez-faire Leadership styles}

The autocratic, democratic, and laissez-faire leadership style is the fundamental aspect of the leadership approaches in relation to Lewin's leadership framework, 1939 (Fentiman-Hall, 2017). The combination of these three leadership styles further develops other leadership models like transformational, instructional, transactional, ethical, distributed, charismatic, strategic, and much more leadership. Thus every leader employs these three leadership styles in the leading process. However, the extent of these leadership styles may simply differ (Cherry, 2019) with each other. That's why these three leadership styles belong to the same continuum where autocratic and democratic leadership style poses each other's opposite poles. These similarities and discrepancies illustrate the relationship between these three leadership styles with each others. For that reason, the researcher sets the hypothesis as:

$\mathrm{H}_{1}$ : There is a significant difference between the autocratic, democratic, and laissez-faire leadership style among school teachers

\section{Methods}

\section{Research Design}

This study is basically based on the post-positivist paradigm as the perspective of this research and it seeks the reality about the leadership styles of school teachers. This research adopted the survey methods as the methodological considerations and it contributes to identifying the facts about leadership styles of school teachers. Thus, this study adopted the quantitative research design and it uses the literature review to support facts which are derived from the self-administer questionnaire.

This study incorporated 345 school teachers as the sample by operating Yamane (1967) formula from 2491 population (e.g. District Education Office [DEO], 2016) at $95 \%$ confidence limit. The researcher espoused cluster sampling as the sampling design in this study.

\section{Measures}

The Likert scale is used as the data collection tools to collect data in this study. This Likert scale is adopted from the Sagepub (n.d.) and it consists 18 Likert items (in Annex I). Among them, authoritarian leadership is measured by items number $1,4,7,10,13$, and 16 . Democratic leadership is measured by items $2,5,8,11,14$, and 17. As well as the remaining items 3, 6, 9, 12, 15, and 18 assess the laissez-faire leadership. These all Likert items consist five responses and these responses were given certain values which strongly disagree (1), disagree (2), neutral (3), agree (4) and strongly agree (5) respectively. Among these responses strongly disagree represents the minimum extent in this scale whereas strongly agree refers to the maximum extent in this continuum. For the measuring purpose, the researcher had summed all the responses in numerical values regards to three factors. The researcher then identified the levels of these leadership styles according to the obtained score where if it is between 26-30 (very high range), 21-25 (high range), 16-20 (moderate range), 11-15 (low range) and 6-10 (very low range) (Sagepub, n.d.) respectively.

The researcher used the self-administer questionnaire to all school teachers to collect data. For this purpose, the researcher distributed the self-administered questionnaire to the teachers by explaining the nature of the study as well as assured them about keeping provided information confidentially. In addition, the researcher also requested them to fill and submit the tools the next day to the researcher. The tool was collected the next day after completion. After collection of all data, the researcher had checked and rechecked the research tool for ensured its quality. 


\section{Data Analysis}

Most part of this study is based on descriptive interpretation and analysis according to its finding. The researcher analyzes the data by including a number of closely related operations such as the establishment of categories, the application of these categories to raw data through coding, tabulation and then drawing the statistical inference. Being quantitative research, the researcher explains the facts by using tables and some basic statistical tools to support the analysis. The researcher identifies the level of leadership styles through the descriptive statistics like frequency, percentage and mean. Similarly, this study also adopted the ANOVA test to analyze the influence of job nature in leadership styles and Karl Pearson correlation for examining the relationship between these leadership styles among school teachers.

\section{Results}

\section{Nature of the Job among Basic School Teachers}

The researcher classified this job nature in three categories: Approved, Contract (Raahat), and Temporary (Niji shrot) respectively. This section adopted descriptive statistics like frequency and percentage to analyze the job nature of basic school teachers in Table 1.

Table 1 - Nature of the Job among School Teachers

\begin{tabular}{lccc}
\hline Job nature & Frequency & Percent & Cumulative Percent \\
\hline Approved & 174 & 50.4 & 50.4 \\
Contract & 57 & 16.5 & 66.9 \\
Temporary & 114 & 33.0 & 100 \\
Total & 345 & 100 & 100 \\
\hline
\end{tabular}

By the nature of the job, the half of the teachers were approved and remaining were temporary $(\mathrm{N}=114, \%$ $=33.0)$ and contract basis teachers $(\mathrm{N}=57, \%=16.5)$ respectively. This table no. 1 divulged that in almost schools temporary teachers were one-third whereas approved was more in numbers. This figure is analogous to the information provided by the MOEST (2018) where approved teachers $(\mathrm{N}=109118)$ were merely three times more than Contract school teachers $(\mathrm{N}=38420)$. Similarly, in context of Dhading district, the approved teachers were the majority $(\mathrm{N}=1642)$ and it was followed by Contract teachers $(\mathrm{N}=849)$ (MOEST, 2018) whereas remaining few four hundred were temporary teachers.

\section{Leadership Styles}

The level of these three leadership styles is determined by the obtained scores in this study and it is derived as follows in table 2 .

Table 2 - Level of leadership styles

\begin{tabular}{|c|c|c|c|c|c|c|c|c|c|}
\hline \multirow[t]{2}{*}{ Leadership style } & & \multicolumn{4}{|c|}{ Level of Leadership Style } & \multirow{2}{*}{ Range } & \multirow{2}{*}{ Min } & \multirow{2}{*}{$\operatorname{Max}$} & \multirow{2}{*}{ Mean } \\
\hline & & Low & Mod & High & VH & & & & \\
\hline Autocratic & $f$ & - & 58 & 230 & 57 & & & & \\
\hline leadership & $\%$ & - & 16.81 & 66.67 & 16.51 & 6 & 20 & 26 & 22.01 \\
\hline Democratic & $f$ & - & - & 115 & 230 & & & & 2617 \\
\hline leadership & $\%$ & - & - & 33.33 & 66.67 & 4 & 24 & 28 & 20.17 \\
\hline Laissez-faire & $f$ & 57 & 230 & 58 & - & 10 & 14 & 24 & 1817 \\
\hline leadership & $\%$ & 16.51 & 66.67 & 16.81 & - & 10 & & & \\
\hline
\end{tabular}

$* f=$ Frequency, $\%=$ Percent, Mod $=$ Moderate, $\mathrm{VH}=$ Very high, Min= Minimum, Max $=$ Maximum 
Table 2 reveals the level of the school teacher in terms of leadership styles. The school teachers have a high level (Mean $=22.67$ ) of autocratic and very high level (Mean $=26.17$ ) of democratic leadership styles. Likewise, the laissez-faire leadership style consists of moderate mean score (18.17) which means school teachers have a moderate level of laissez-faire style in the school. This information makes sense that the school teachers adopt a more democratic leadership style than another leadership style while executing their work and they give the least preference to the laissez-faire leadership style in school.

\section{Autocratic Leadership Styles}

The autocratic leadership style is that leadership system which gives full authority to the leaders and as a result, followers only got minimum participation in decision making process. Moreover, the autocratic leadership style includes some features which make this style different from other styles. These features are; leadership do not consult members in decision making process (Cherry, 2018), leaders determine the policies and plans, leaders give the work and duties to the followers, leaders strictly monitor to the followers and provide punishment as well as incentive to followers based on personalizes judgments (Yuki, 1994 as cited in Nyiha, 2015). In this context, the table 2 shows the level of autocratic leadership styles residing in the school teachers and majority of teachers $(\mathrm{N}=230, \%=66.67)$ exhibits the high autocratic leadership styles in the school. Likewise, the mean statistics of autocratic leadership style is 22.67 which is itself the high level in the continuum of scale. This data reveals that the majority of teachers adopt the high pace of autocratic leadership style in school.

\section{Democratic Leadership Styles}

Democratic leadership style is known as the authority decentralizing phenomena which encourage participatory planning and mutual understanding with communicative leadership approach (Isundwa, 2015) in organization. The major features which contribute to determining democratic leadership styles are; leaders shared decision making process with followers and invite contributions from followers but still leaders retain the power of taking decision in organization (Oyetunyi, 2006). Considering it, the table 2 reflects that the majority school teachers $(\mathrm{N}=230, \%=66.67)$ adopts very high level of democratic leadership styles but remaining $33.33 \%(\mathrm{~N}=115)$ shows high level of democratic attitudes. This information reveals that the almost all teachers have a high level of democratic attitude in their work place as the democratic leadership styles.

\section{Laissez-faire Leadership Styles}

Laissez-faire leadership style is that attitudes of leader where they refuse to clarify the goals and standards to the followers (Hafez, 2017) and followers also do not have any expectation towards organization. This leadership styles encompasses some features that the leaders do not make decision, leaders and followers both were not available when they are needed, and leaders do not bear responsibilities in the organization (Kormaz, 2007 as cited in Nyiha, 2015). The derived finding in table 2 reflects the majority (66.7\%) reveals the moderate level of laissez-faire leadership style among school teachers. The remaining teachers adopt low (N $=57, \%=16.51)$ and high $(\mathrm{N}=58, \%=16.81)$ level respectively. This information further shows that the school teachers collectively adopt the laissez-faire leadership style in moderate level.

\section{Leadership Style across Job Nature}

This section aims to examine the leadership style of basic school teachers across their job nature (Approved, Contract and Temporary). The considerable differences were obtained separately through the Autocratic leadership style, Democratic leadership style, and laissez-faire leadership style by operating the one-way ANOVA and Post Hoc test. The ANOVA test provided with the 'F' score and ' $p$ ' value (2-tailed) and Post Hoc projected Mean Differences (MD) and Standard Error (SE) in Table 3 and 4 respectively. 
Table 3 - ANOV A test: Leadership styles in relation to the nature of the job

\begin{tabular}{llccccc}
\hline Leadership style & Job nature & $\mathbf{N}$ & Mean & Std. Deviation & F & Pvalue \\
\hline \multirow{3}{*}{ Autocratic leadership } & Approved & 174 & 1.67 & .48 & & .00 \\
& Contract & 57 & 2.00 & .00 & 13.92 & .51 \\
\multirow{2}{*}{ Democratic leadership } & Temporary & 114 & 2.50 & .48 & & .07 \\
& Approved & 174 & 1.67 & .00 & & \\
& Contract & 57 & 2.00 & .51 & & .00 \\
Laissez-faire leadership & Temporary & 114 & 1.50 & .00 & & .00 \\
& Approved & 174 & 3.00 & .51 & & \\
\hline
\end{tabular}

Table 4 - Post Hoc test: Leadership styles in relation to the nature of the job

\begin{tabular}{|c|c|c|c|c|c|}
\hline Dependent Variable & (I) Job Nature & (J) Job Nature & Mean Difference (I-J) & Std. Error & Sig. \\
\hline \multirow{3}{*}{ Autocratic leadership } & Contract & $\begin{array}{l}\text { Temporary } \\
\text { Approved }\end{array}$ & $\begin{array}{l}-.50 \\
.33\end{array}$ & $\begin{array}{l}.21 \\
.20\end{array}$ & $\begin{array}{l}.05 \\
.23\end{array}$ \\
\hline & Temporary & $\begin{array}{l}\text { Contract } \\
\text { Approved }\end{array}$ & $\begin{array}{l}.50 \\
.83^{*}\end{array}$ & $\begin{array}{l}.21 \\
.15\end{array}$ & $\begin{array}{l}.05 \\
.00\end{array}$ \\
\hline & Approved & $\begin{array}{l}\text { Contract } \\
\text { Temporary }\end{array}$ & $\begin{array}{l}-.33 \\
-.83^{*}\end{array}$ & $\begin{array}{l}.20 \\
.15\end{array}$ & $\begin{array}{l}.23 \\
.00\end{array}$ \\
\hline \multirow{3}{*}{ Democratic leadership } & Contract & $\begin{array}{l}\text { Temporary } \\
\text { Approved }\end{array}$ & $\begin{array}{l}.50 \\
.33\end{array}$ & $\begin{array}{l}.21 \\
.20\end{array}$ & $\begin{array}{l}.05 \\
.23\end{array}$ \\
\hline & Temporary & $\begin{array}{l}\text { Contract } \\
\text { Approved }\end{array}$ & $\begin{array}{l}-.50 \\
-.16\end{array}$ & $\begin{array}{l}.21 \\
.15\end{array}$ & $\begin{array}{l}.05 \\
.54\end{array}$ \\
\hline & Approved & $\begin{array}{l}\text { Contract } \\
\text { Temporary }\end{array}$ & $\begin{array}{l}-.33 \\
.16\end{array}$ & $\begin{array}{l}.20 \\
.15\end{array}$ & $\begin{array}{l}.23 \\
.54\end{array}$ \\
\hline \multirow{3}{*}{ Laissez-faire leadership } & Contract & $\begin{array}{l}\text { Temporary } \\
\text { Approved }\end{array}$ & $\begin{array}{l}-1.50^{*} \\
-1.00^{*}\end{array}$ & $\begin{array}{l}.13 \\
.13\end{array}$ & $\begin{array}{l}.00 \\
.00\end{array}$ \\
\hline & Temporary & $\begin{array}{l}\text { Contract } \\
\text { Approved }\end{array}$ & $\begin{array}{l}1.50^{*} \\
.50^{*}\end{array}$ & $\begin{array}{l}.13 \\
.10\end{array}$ & $\begin{array}{l}.00 \\
.00\end{array}$ \\
\hline & Approved & $\begin{array}{l}\text { Contract } \\
\text { Temporary }\end{array}$ & $\begin{array}{l}1.00^{*} \\
-.50^{*}\end{array}$ & $\begin{array}{l}.13 \\
.10\end{array}$ & $\begin{array}{l}.00 \\
.00 \\
\end{array}$ \\
\hline
\end{tabular}

Table 3 reveals the ' $F$ ' and ' $p$ ' values via computing the one-way ANOVA test. The obtained p-value denotes identification the significant differences based on comparison of alpha (0.05) value. This table elucidates that among the leadership styles, the first leadership style: autocratic consists of the significant differences $(\mathrm{F}=$ $13.92, p=.00$ ) across the job nature of the teachers. Moreover, the Post Hoc test in table 4, discloses the degree of differences between temporary and approved teachers $(\mathrm{MD}=.833, \mathrm{SE}=1.58)$ in relation to the autocratic leadership style. This statistic reflects that the temporary teachers allow more autocratic leadership whereas an approved teacher poses the least.

Likewise, there is no presence of significant differences $(\mathrm{F}=2.78, p=.07)$ in democratic leadership styles in relation of job nature of school teachers. Despite it, the contract teachers exhibit few more (Mean $=2.00, \mathrm{SD}$ $=.00)$ democratic leadership qualities than temporary basis teachers $($ Mean $=1.50, \mathrm{SD}=.51)$. Similarly, the job nature of the teacher makes predictable differences in laissez-faire leadership style $(\mathrm{F}=58.50, p=.00)$. In 
relation to this, the significant differences in laissez-faire leadership style is due to vary in-between contracttemporary $(\mathrm{MD}=1.50, \mathrm{SE}=1.39)$, contract-approved $(\mathrm{MD}=1.00, \mathrm{SE}=1.31)$, and temporary-approved $(\mathrm{MD}=.50, \mathrm{SE}=.10)$ teachers respectively. Overall these statistics reveals that the job nature makes influences in autocratic and laissez-faire leadership style.

\section{The relationship among Leadership Styles}

This section gives the effort to determine the relationship between the three leadership styles; autocratic, democratic and laissez-faire respectively among the basic school teachers of Dhading. The basis of analysis was the Karl Pearson coefficient value $(p)$. The result has been presented in table 5 .

Table 5 - Correlation between three leadership styles

\begin{tabular}{lccc}
\hline Leadership styles & $\begin{array}{c}\text { Autocratic } \\
\text { Leadership }\end{array}$ & $\begin{array}{c}\text { Democratic } \\
\text { leadership }\end{array}$ & $\begin{array}{c}\text { Laissez-faire } \\
\text { leadership }\end{array}$ \\
\hline Autocratic Leadership & 1 & 1 & \\
Democratic leadership & $.612(.196)$ & $-.612(.196)$ & 1 \\
Laissez-faire leadership & $-.500(.312)$ &
\end{tabular}

** Correlation is significant at the 0.01 level (2-tailed).

Table 5 illustrates that there is no significant relation $(r=.612, p>.01)$ between autocratic leadership style and democratic leadership style in this study. In addition, it shows that there was significantly absent of relationship between autocratic and laissez-faire leadership style $(\mathrm{r}=-.500, p>.01)$ as well as democratic and laissez-faire leadership style $(r=-.612, p>.01)$ respectively. Thus this information reflects that there is no significant relationship between these three leadership styles; autocratic, democratic and laissez-faire respectively.

\section{Discussion}

Leadership style encompasses a variety of conducts of a leader and leaders adopt some extent of them as a leadership style in order to succeed (Shamaki, 2015). No one can adopt completely the one particular leadership style. However, they can adopt it to more extent and they further adapt it with another leadership style in school leadership process (Drobout \& Rosu, 2012). At the same time, school teachers collaboratively adopt more leadership styles to led followers. This result is similar to Isundwa (2015) and scholar derived that school teachers behave these three leadership styles: autocratic, democratic and laissez-faire in a collaborative form. However, the crucial issue is, which leadership style was adopted in a higher extent by the teachers? This study derived that most of the school teachers prefer high autocratic as well as democratic instead of laissez-faire leadership style in the school. Moreover, they adopt an only a moderate degree of laissez-faire leadership style in the educational process.

Similarly, the job nature (e.g. approved, contract basis, and temporary) also influences the leadership style of the school teachers. In the context of Nepal, the nature of the job determines the power exercises, right and responsibilities, and facilities which were provided to the school teachers. The delegated power, rights and responsibilities are not equal among the school teachers. However, they perform similar types of jobs in the school. This bigotry among teachers is due to their permanency or temporality (Lynch \& Lodge, 2002) in the job. As a result, it makes differences in leadership style (particularly autocratic and laissez-fair) amid school teachers. 
The presence of significant differences in autocratic leadership style among school teachers was due to their job nature. In the Nepali context, the autocratic leadership style is influencing due to the difference between the approved basis and temporary teachers. In relation to the nature of the job, the approved teachers are more secure in the job than temporary teachers (e.g. Balze, 2017). In addition, approved teachers are provided more job training, experiences, and exposure so they become less authoritarian in comparison to the temporary teachers.

Likewise, the job nature of school teachers also makes significant differences in laissez-faire leadership styles. In the context of Nepal, these three types of job natures are distinct with each others due to dissimilarity in power exercise, participation in the decision making process, delegated rights and responsibilities, the security of a job, and provided benefits, etc. Considering it, the permanent teachers are found more responsible in school leadership than other teachers (Department of Education and Training [DOET], 2006) but in fact, they exhibit more laissez-faire leadership style than contract teachers. Performing high level of laissez-faire leadership refers that these teachers neglect their job duties and responsibilities (e.g. Mahmood, 2007). Some researchers (e.g. Thapa, 2011) divulge that the high security in the job makes the employee more laissez-faire in the context of Nepal. These approved school teachers have less fear of losing a job (Tapper, 2018) than contract teachers even they perform low in school.

Considering it, the temporary teachers exhibit high laissez-faire leadership styles than other teachers. The exhibition of high laissez-faire leadership styles is due to the low teaching experiences and exposure among school teachers. In addition, most of the temporary teachers took teaching job as the stepping stone in Nepali context. As a result, they do not well accomplish their duty which is one of the major causes of poor leadership practices and low academic achievement in the school.

In addition, the finding of this study also reveals that there is no significant relationship between leadership styles. It refers that the leadership styles do not influence with each other due to its distinct nature. Dudovskiy (2013) found that the democratic and autocratic leadership styles lie in the same continuum as the opposite poles of leadership. These findings and literature disclose that these three leadership styles are distinct from each other. So there is no more correlation between them. The absent of this relationship between leadership styles makes these all leadership style distinct from each other. And this distinctness between leadership styles influences the work performances (Chua, Basit, \& Hassan, 2018), effectiveness, institutional development of the organization (Igbaekemen \& Odivwri, 2015; Nanjundeswaraswamy \& Swamy, 2014) and achievement of teachers.

\section{Conclusion}

The three leadership styles (autocratic, democratic and laissez-faire) collaboratively exist in the teachers but they prefer high autocratic and democratic leadership style. These both leadership styles are overlapping with each other's while providing leadership in the school. In contrary, the school teachers behave moderately to the laissez-faire leadership style and this leadership style do not establish the correlation between other leadership styles. Likewise, due to lack of equal facility, access to power exercise in relation to the job nature significantly influences the leadership styles (e.g. autocratic and laissez-faire) of school teachers. This dissimilarity in job nature among teachers prominently affects in the job performances and academic achievements in the school. Finally, these three leadership styles are different from each other's which also creates a discrepancy in work performances, effectiveness, and achievement.

\section{Implications}

This research contributes to scrutinize the contribution of job nature in leadership style among school setting. However, at a rest, there are several aspects (e.g. policy, school leader) which need to investigate about 
leadership style amid teachers. So this effort can be a useful pathway for another imminent investigator to study the leadership style of academia. Thus, this research lifts "Job nature on leadership style: Why it brings differences in academia?" as the research concerns at its end.

\section{References}

Adeyemi, T. O. (2011). Principals' leadership styles and teachers' job performance in senior secondary schools in Ondo state, Nigeria. Current Research Journal of Economic Theory, 3(3), 84-92.

Al-Maki, M., \& Juan, W. (2018). Impact of laissez-faire leadership on role ambiguity and role conflict: Implications for job performance. International Journal of Innovation and Economic Development, 4(1), 29-43. doi:10.18775/ijied.1849-7551-7020.2015.41.2003

Balz, A. (2017). Cross-national variations in the security gap: Perceived job insecurity among temporary and permanent employees and employment protection legislation. European Sociological Review, 33(5), 675692. doi:10.1093/esr/jcx067

Bhatti, N., Maitlo, G. M., Shaikh, N., Hashmi, M. A., \& Shaikh, F. M. (2012). The impact of autocratic and democratic leadership style on job satisfaction. International Business Research, 5(2), 192-201. doi:10.5539/ibr.v5n2p192

Chaudhary, A. Q., \& Javed, H. (2012). Impact of transactional and laissez faire leadership style on motivation. International Journal of Business and Social Science, 3(7), 258-264.

Cherry, K. (2018, September 11). Autocratic leadership: Key characteristics, strengths, and weakness of autocratic leadership. Verywell Mind. Retrieved from https://www.verywellmind.com/what-isautocratic-leadership-2795314

Cherry, K. (2019, March 11). Leadership styles and frameworks you should know. Verywell Mind. Retrieved from https://www.verywellmind.com/leadership-styles-2795312

Chua, J., Basti, A., \& Hassan, Z. (2018). Leadership style and its impact on employee performance. International Journal of Accounting and Business Management, 6(1), 80-94. doi:10.24924/ijabm/2018.04/v6.iss1.80.94

Clayton, M. (2017, May 2). Robert Tannenbaum and Warren Schmidt: Leadership continuum. Management Pocket Books. Retrieved from https://www.pocketbook.co.uk/blog/2017/05/02/robert-tannenbaumwarren-schmidt-leadership-continuum/

Department of Education and Training. (2006). Teachers' code of professional practice. Canberra: Author.

District Education Office. (2016). Educational report of Dhading district - 2016. Retrieved from http://www.deodhading.gov.np

Drobot, L., \& Rosu, M. (2012, 24-26 May ). Teachers' leadership style in the classroom and their impact upon high school students. Paper presented at the International conference of scientific paper AFASES 2012, Brasov.

Dudovisky, J. (2013, March 30). Leadership continuum theory by Tannerbaum and Schmidt. Research Methodology. Retrieved from http:// research-methodology.net/leadership-continuum-theory-bytannerbaum-and-schmidt/

Fentiman-Hall, S. (2017). Are you an autocrat, laissez-faire, or transformational leader? From Kurt Lewin's 1939 leadership framework research, to more modern ideas about transformational leaders, there are 
almost as many styles of leadership as leaders. Virgin. Retrieved from https://www.virgin.com/entrepreneur/autocratic-democratic-or-laissez-faire-whats-your-leadershipstyle

Fries, K. (2018). 8 essential qualities that define great leadership. Forbes. Retrieved from https://www.forbes.com/sites/kimberlyfries/2018/02/08/8-essential-qualities-that-define-greatleadership/\#4e7cf5733b63

Gaskel, C. (2016, May 17). The nine types of employees and how to motivate them. The Guardian. Retrieved from https://www.theguardian.com/careers/2016/may/17/the-nine-types-of-employees-and-howto-motivate-them

Germano, M. A. (2010). Leadership style and organizational impact. Libray workforce: HR E News for Today's Leaders. Retrieved from http://ala-apa.org/newsletter/2010/06/08/spotlight/

Hafez, A. (2017). How do autocratic, democratic and laisse--faire leadership differ. Retrieved from https://www.linkedin.com/pulse/how-do-autocratic-democratic-laissez-faire-leadership-ahmed-hafez

Igbaekemen, G. O., \& Odivwri, J. E. (2015). Impact of leadership style on organizational performance: A critical literature review. Arabian Journal of Business and Management Review, 5(5), 142-149. doi:10.4172/2223-5833.1000142

Isundwa, S. J. (2015). The Influence of Leadership Styles on Students Academic Acbievement in Secondary Schools: A Case of Selected Secondary Schools in Morogoro Municipality. (Master degree dissertation, Open University of Tanzania). Retrieved from http://repository.out.ac.tz/1137/

Kale, M., \& Ozdelen, E. (2014). The analysis of teacher leadership styles according to teachers' perceptions in primary schools. Procedia - Social and Behavioral Sciences, 152, 227-232.

Khan, M. S., Khan, I., Qureshi, Q. A., Ismail, H. M., Rauf, H., Latif, A., \& Tahir, M. (2015). The styles of leadership: A critical review. Public Policy and Administration Research, 5(3), 87-92.

Kumari, D. U. (2016). Comparative study of leadership styles among teachers of private and govt. senior secondary schools. International Education and Research Journal, 2(11), 65-66.

Lester, C. N. (1975). Leadership styles - a key to effectiveness. Journal of Extension, November/December, 3-11.

Lucky, E. O., Minai, M. S., \& Rahman, H. A. (2013). Impact of Job Security on the Organizational Performance in a Multiethnic Environment. Research Journal of Business Management 7, 64-70. doi:http://dx.doi.org/10.3923/rjbm.2013.64.70

Lynch, K., \& Lodge, A. (2002). Equality and power in schools: Redistribution, recognition and representation. London: RoutledgeFalmer.

Mahmood, K. (2007). Least common multiple of teacher leadership styles: Implications for classroom. . Bulletin of Education and Research, 29(2), 19-42.

McCallum, J. S. (2013). The followership: The other types of leadership. Ivey Business Journal: Improving the Practice of Management, September-October (2013). Retrieved from https://iveybusinessjournal.com/publication/followership-the-other-side-of-leadership/.

Ministry of Education, Science and Technology. (2018). Educational brochure 2017. Kathmandu: Author.

Mwaisaka, D. M., K’Aol, G., \& Ouma, C. (2019). Influence of supportive leadership style on employee job satisfaction in commercial banks in Kenya. Journal of Human Resource and Leadership, 4(1), 44-66. 
Nanjundeswaraswamy, T. S., \& Swamy, D. R. (2014). Leadership styles. Advances in Management, 7(2), 57-62.

Northouse, P. G. (2010). Leadership: Theory and practice (5th ed.). New Delhi: Sage publications India Pvt. Ltd.

Nyiha, G. M. (2015). Influence of principals leadership styles on teachers job satisfaction in public secondary schools in Kiambu sub-county, Kiambu county, Kenya. (Master of Education research project on educational administration, University of Nairobi). Retrieved from http://erepository.uonbi.ac.ke/bitstream/handle/11295/92821/Nyiha_Influence

Ojokuku, R. M., Odetayo, T. A., Sajuyigbe, A. S. (2012). Impact of leadership style on organizational performance: A case study of Nigerian Banks. American Journal of Business and Management, 1(4), 202 207. doi:10.11634/216796061706212

Oyetunyi, C. O. (2006). The relationship between leadership styles and school climate: Botswana secondary schools. (Doctor of Philosophy thesis, University of South Africa). Retrieved from http:/ / uir.unisa.ac.za/bitstream/handle/10500/2354/thesis.pdf;jsessionid=7055858573DED1078C8 D45DC05B964D8? sequence $=1$

Rahmat, R., Ramly, M., Mallongi, S., \& Kalla, R. (2019). The leadership style effect on the job satisfaction and the performance. Asia Pacific Journal of Management and Education, 2(1), 1-13. doi:10.3253/apjme.V2i1.376

Sagepub. (n. d.). 3.1 leadership styles questionnaires. Retrieved from http://www.sdececonferenceorg.doodlekit.com/file/323169/Leadership_Styles_Questionaire.pdf.

Sandling, J. (2014). Laissez faire leadership. Retrieved from https://jonathsandling.com/laissez-faire-leadership/.

Shamaki, E. B. (2015). Influence of leadership style on teacher's job productivity in public secondary schools in Taraba State, Nigeria. Journal of Education and Practice, 6(10), 200-203.

Skogstad, A., Einarsen, S., Torsheim, T., Aasland, M. S., \& Hetland, H. (2007). The destructiveness of laissezfaire leadership behavior. Journal of Occupational Health Psychology, 12(1), 80-92. doi:10.1037/10768998.12.1.80

Tapper, J. (2018, May 13). Burned out: Why are so many teachers quitting or off sick with stress? The Guardian. Retrieved from https://www.theguardian.com/education/2018/may/13/teacher-burnoutshortages-recruitment-problems-budget-cuts

Tarsik, N. F., Kassim, N. A., \& Nasharudin, N. (2014). Transformational, transactional or laissez-faire: What styles do university librarians practice? Journal of organizational management studies, 2014(2014), 1-14. doi: $10.5171 / 2014.194100$

Thapa, A. (2011). Does private school competition improve public school performance? The case of Nepal. (Unpublished doctoral thesis), University of Columbia: New York.

Yamane, T. (1967). Elementary sampling theory. Englewood Cliffs, NJ: Prentice-Hall.

Yang, I. (2015). Positive effects of laissez-faire leadership: Conceptual exploration. Journal of Management Development, 34(10), 1246-1261. doi:10.1108/JMD-02-2015-0016 


\section{Annex I}

\section{CONTRIBUTION OF JOB NATURE ON LEADERSHIP STYLES AMONG ACADEMIA}

Age

Nature of job

Educational Status
: Temporary / Contract / Permanent

: 10+2 / Bachelor / Master / M.Phil-PhD

Sex : Male / Female / Third

Likert Scale

Please tick mark $(\sqrt{ })$ the appropriate number according to the following given indicator Indicator:

\begin{tabular}{|l|l|l|l|l|} 
Strongly disagree & Disagree & Neutral & Agree & Strongly agree \\
\hline
\end{tabular}

\section{Leadership Styles of 'Teachers}

\begin{tabular}{|l|l|l|l|l|l|c|}
\hline S.N. & \multicolumn{1}{|c|}{ Statement } & \multicolumn{3}{|c|}{ Scale } \\
\hline 1 & $\begin{array}{l}\text { Employees need to be supervised closely, or they are not likely to do their } \\
\text { work }\end{array}$ & 1 & 2 & 3 & 4 & 5 \\
\hline 2 & Employees want to be a part of the decision - making the process. & 1 & 2 & 3 & 4 & 5 \\
\hline 3 & $\begin{array}{l}\text { In complex situations, leaders should let subordinates work problems out on } \\
\text { their own. }\end{array}$ & 1 & 2 & 3 & 4 & 5 \\
\hline 4 & It is fair to say that most employees in the general population are lazy. & 1 & 2 & 3 & 4 & 5 \\
\hline 5 & Providing guidance without pressure is the key to being a good leader & 1 & 2 & 3 & 4 & 5 \\
\hline 6 & $\begin{array}{l}\text { Leadership requires staying out of the way of subordinates as they do their } \\
\text { work. }\end{array}$ & 1 & 2 & 3 & 4 & 5 \\
\hline 7 & $\begin{array}{l}\text { As a rule, employees must be given rewards or punishments in order to } \\
\text { motivate them to achieve organizational objectives. }\end{array}$ & 1 & 2 & 3 & 4 & 5 \\
\hline 8 & $\begin{array}{l}\text { Most workers want frequent and supportive communication from their } \\
\text { leaders. }\end{array}$ & 1 & 2 & 3 & 4 & 5 \\
\hline 9 & As a rule, leaders should allow subordinates to appraise their own work. & 1 & 2 & 3 & 4 & 5 \\
\hline 10 & Most employees feel insecure about their work and need direction. & 1 & 2 & 3 & 4 & 5 \\
\hline 11 & $\begin{array}{l}\text { Leaders need to help subordinates accept responsibility for completing their } \\
\text { work. }\end{array}$ & 1 & 2 & 3 & 4 & 5 \\
\hline 12 & $\begin{array}{l}\text { Leaders should give subordinates complete freedom to solve problems on } \\
\text { their own. }\end{array}$ & 1 & 2 & 3 & 4 & 5 \\
\hline 13 & $\begin{array}{l}\text { The leader is the chief judge of the achievements of the members of the } \\
\text { group. }\end{array}$ & 1 & 2 & 3 & 4 & 5 \\
\hline 14 & It is the leader's job to help subordinates find their "passion" & 1 & 2 & 3 & 4 & 5 \\
\hline 15 & In most situations, workers prefer little input from the leader. & 1 & 2 & 3 & 4 & 5 \\
\hline 16 & $\begin{array}{l}\text { Effective leaders give orders and clarify procedures. } \\
17\end{array}$ & People are basically competent and if given a task will do a good job. & 2 & 3 & 4 & 5 \\
\hline 18 & In general, it is best to leave subordinates alone. & 2 & 3 & 4 & 5 \\
\hline
\end{tabular}

* Adopted from Sagepub (n.d.)

Thank you...... 